\title{
OECDpublishing
}

\section{CROSS-BORDER CO-OPERATION NETWORKS IN WEST AFRICA}

\section{WEST AFRICAN PAPERS}

June 2017 No. 06 



\section{CROSS-BORDER CO-OPERATION NETWORKS IN WEST AFRICA}

This paper has been prepared by

OLIVIER WALTHER

University of Southern Denmark 


\section{WEST AFRICAN PAPERS}

The West African Papers series explores African socio-economic, political and security dynamics from a regional and multidisciplinary perspective. It seeks to stimulate discussion and gather information to better anticipate the changes that will shape future policies. The series is designed for a wide audience of specialists, development practitioners, decision makers and the informed public. Papers are available in English and/or French, and summaries are available in both languages. Initiated by the Sahel and West Africa Club (SWAC) to highlight and promote West African issues, the work presented is prepared by its Secretariat, Members and partners, other OECD departments, related international organisations, associated experts and researchers.

For more information on the Sahel and West Africa Club: http://www.oecd.org/swac.

Please cite this publication as:

Walther, O. (2017), "Cross-border Co-operation Networks in West Africa", West African Papers, No. 06, OECD Publishing, Paris.

http://dx.doi.org/10.1787/73298292-en

Author contact: ow@sam.sdu.dk

ISSN 2414-2026

OECD Working Papers should not be reported as representing the official views of the OECD or of its member countries. The opinions expressed and arguments employed are those of the authors.

This document and any map included herein are without prejudice to the status of or sovereignty over any territory, to the delimitation of international frontiers and boundaries and to the name of any territory, city or area.

Working Papers describe preliminary results or research in progress by the author(s) and are published to stimulate discussion on a broad range of issues on which the OECD works. Comments on Working Papers are welcomed, and may be sent to the Sahel and West Africa Club, OECD, 2 rue André-Pascal, 75775 Paris Cedex 16, France.

Authorised for publication by Laurent Bossard, Director, Sahel and West Africa Club Secretariat (SWAC/OECD).

(C) OECD 2017

You can copy, download or print OECD content for your own use, and you can include excerpts from OECD publications, databases and multimedia products in your own documents, presentations, blogs, websites and teaching materials, provided that suitable acknowledgment of OECD as source and copyright owner is given. All requests for commercial use and translation rights should be submitted to rights@oecd.org. 


\begin{abstract}
Long seen as artificial barriers inherited from decolonisation, West African borders now lie at the heart of policies designed to encourage regional trade and combat political instability. This rediscovery of the peripheries of the nation state has fostered a proliferation of institutional initiatives that aim to cultivate co-operation between countries, regions and municipalities while ensuring the protection and promoting the interests and rights of the people living in border regions. Despite these regional initiatives, the effective functioning of cross-border co-operation still remains largely unknown across West Africa. The purpose of this paper is to fill that gap, with an analysis of both the social structure and the geography of West African governance networks. On the basis of this structural and geographic analysis, policy recommendations are formulated aimed at implementing policies that are more place-based, more attentive to relations between the actors at play in co-operation, and more specifically adapted to the constraints and opportunities of the West African region.
\end{abstract}

Keywords: cross-border co-operation, networks, governance, regional integration, West Africa JEL classification: R58, O43, O18, O550, O190

\begin{abstract}
ABOUT THE AUTHOR
Olivier J. Walther is Associate Professor in Political Science at the University of Southern Denmark and a Visiting Professor at the Division of Global Affairs at Rutgers, The State University of New Jersey.

He received his PhD in geography from the University of Lausanne. His research has pioneered the introduction of social network analysis to the study of trade, cross-border co-operation and terrorism in West Africa. His current research project addresses the effects of national boundaries on cross-border co-operation and policy networks in 18 West African countries. Professor Walther has received support for his work from the European Commission, the OECD, the European Spatial Planning Observatory, the research funds of Luxembourg and Denmark, and the Carlsberg Foundation. He has collaborated with the World Food Program, the World Bank Trade Unit and the United Nations Counter-terrorism Executive Directorate. Dr Walther is the Africa Editor of the Journal of Borderlands Studies and on the executive committee of the African Borderlands Research Network (ABORNE).
\end{abstract}





\section{TABLE OF CONTENTS}

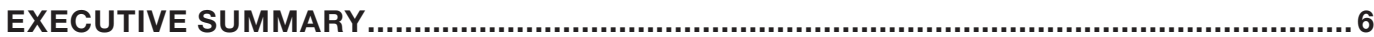

BORDER AREAS AND GOVERNANCE NETWORKS ....................................................

Potential: Where could cross-border co-operation be developed? .....................................7

Current situation: Where is cross-border co-operation being developed? .....................10

Vision: Where should cross-border co-operation be developed? ......................................16

COMBINING THE THREE DIMENSIONS OF CROSS-BORDER CO-OPERATION .............. 19

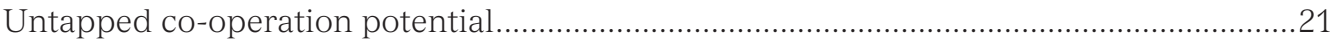

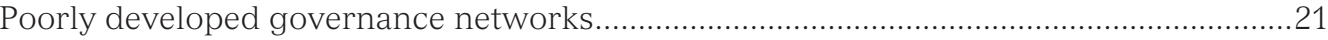

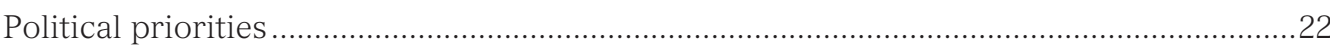

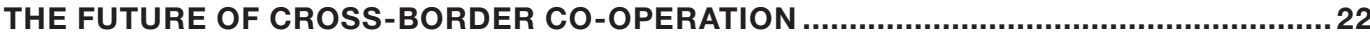

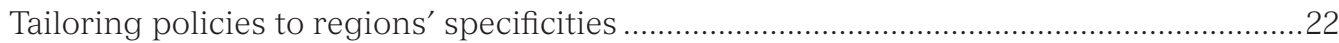

An integration model between institutions and functional interactions .........................23

USING A RELATIONAL APPROACH TO UNDERSTAND CROSS-BORDER

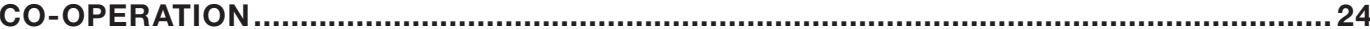

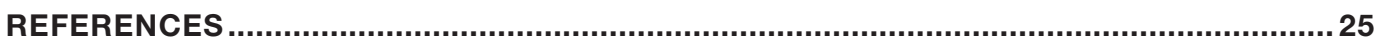




\section{EXECUTIVE SUMMARY}

T oday, West African borders lie at the heart of policies designed to encourage regional trade and combat political instability. This rediscovery of the peripheries of the nation state has fostered the proliferation of institutional initiatives that aim to cultivate co-operation between countries, regions and municipalities. Despite these initiatives, the effective functioning of cross-border co-operation still remains largely unknown across West Africa: a great quantity of research has covered the legislative and institutional principles of co-operation, but the structure of the governance networks connecting the organisations and individuals involved in cross-border projects have not yet been discussed in any systematic analysis. Similarly, the geographical character of border zones and the manner in which borders affect the operation of governance networks have also been somewhat neglected, despite their crucial significance in the implementation of cross-border projects.

The purpose of this paper, produced from research conducted by the OECD Sahel and West Africa Club into cross-border co-operation and governance networks in West Africa, is to fill that gap, with an analysis of both the social structure and the geography of West African governance structures. Three political recommendations have been formulated on the basis of an analysis of 137 actors involved in local and regional co-operation.

The analysis suggests, first, that cross-border policies should draw on the considerable diversity of West African regions. These place-based policies should take account of the range of needs, institutional systems and level of development of West African regions and provide public goods adapted to the specific socio-economic challenges of each region. The considerable degree of heterogeneity in West African border zones suggests that investment should be focused on regions which boast the greatest potential, have already set up governance networks or are acknowledged as priority areas by political decision-makers.

The next finding is that the political vision of cross-border co-operation in West Africa draws on two broad integration models: a model inspired by the EU which gives priority to institutional structures, and a model shaped by American influences and focused on interactions between socio-economic actors. In a context typified by both the proliferation of intergovernmental organisations and a preponderance of informal interactions, it is by no means certain that either model is really suited to the opportunities and constraints faced by co-operation actors in West Africa. In the long term, the success of cross-border co-operation will be determined by the adoption of an integration model that is more closely bound to the socio-economic and political specificities of the region.

Last, the research shows that cross-border co-operation ought to be more systematically broached from the point of view of relationships, i.e. by considering the interactions that take place between its actors (information and power networks). Focusing attention solely on the institutional characteristics of regional organisations, countries and local authorities will fail to reveal the way in which cross-border co-operation actually works, whereas its effectiveness often relies on interpersonal relations between actors of very different kinds. The analysis of social networks is therefore a research tool adapted to the understanding of fluid social structures such as the decision-makers involved in cross-border co-operation. The ability to visualise the connections that actually exist in a social group also provides local communities and non-governmental organisations with an empowerment tool and an intervention tool for international organisations and governments.

This kind of approach remains underutilised in development, but could lead to new applications in other fields that are relational in nature, such as trade, migration and conflict, provided that data recording the relationships between social actors are more systematically collected. 


\section{BORDER AREAS AND GOVERNANCE NETWORKS}

- ince the 1960s, the 32000 kilometres of land borders that delineate West Africa, from

Dakar to N'Djamena have never been as central to the implementation of development policies as they are today. Long seen as artificial barriers inherited from decolonisation, these borders now lie at the heart of policies designed to encourage regional trade and combat political instability. Cross-border dynamics represent a fundamental dimension of trade flows, subverting the laws of nation states, as in illegal trafficking and terrorism, which exploit the highly porous borders for the purpose of trading arms, drugs and migrants or carrying out attacks in neighbouring countries.

This rediscovery of the peripheries of the nation state has fostered the proliferation of institutional initiatives that aim to cultivate co-operation between countries, regions and municipalities while ensuring the protection and promoting the interests and rights of the people living in border regions. Ever since the landmark speech on cross-border areas by the President of Mali, Alpha Oumar Konaré, in 2002, the Economic Community of West African States (ECOWAS) and the African Union (AU) have both launched programmes specifically dedicated to borders. In 2011, the West African Economic and Monetary Union (UEMOA) initiated a pilot operation with the first of the border control posts located in Sinkansé (Burkina Faso-Togo border) between member states. More recently, the adoption in 2014 of the Niamey Convention on cross-border co-operation represented a significant step forward in terms of acknowledging the need for special legislation to develop cross-border activities.

Despite these regional initiatives, the effective functioning of cross-border co-operation still remains largely unknown across West Africa: a great quantity of research has covered the legislative and institutional principles of co-operation (SWAC/OECD, 2007; AEBR, 2012; Enda Diapol, 2007), but the structure of the governance networks connecting the organisations and individuals involved in cross-border projects have not, until now, been discussed in any systematic analysis. Similarly, the geographical character of border zones and the manner in which borders affect the operation of governance networks have also been somewhat neglected, despite their crucial significance in the implementation of cross-border projects.

The purpose of this paper, based on work by the OECD Sahel and West Africa Club on cross-border co-operation and policy networks in West Africa (SWAC/OECD, 2017), is to fill that gap, with an analysis of both the social structure and the geography of West African governance structures. Proceeding from this structural and geographic analysis, political recommendations will be formulated that strive to deploy policies that are more place-based, more attentive to relations between the actors at play in co-operation, and more specifically adapted to the constraints and opportunities of the West African region. 


\section{THREE DIMENSIONS OF CROSS-BORDER CO-OPERATION}

ross-border co-operation is a complex integration process that can be broken down into three dimensions, according to whether the analysis is focused on the border regions' potential for co-operation, the current structure of cross-border governance networks or political decision-makers' vision of cross-border co-operation.

\section{Potential: Where could cross-border co-operation be developed?}

West African regions' potential to work together across national borders represents the first dimension of co-operation. Based on a mapping analysis of seven political and socioeconomic indicators (Table 1), it is possible to examine the extent to which social, economic and political disparities are either a source of synergies for cross-border co-operation or an obstacle to institutional cross-border initiatives. Some indicators, such as the population potential (Map 2), are based on the interactions that connect cross-border regions to each other: one, for example, consists in measuring the number of people who can in theory be reached within four hours of a border market, given the current state of the African road network. Other indicators, such as poverty rate differentials between adjacent regions, relate to the convergence process between border regions; in this case the tendency of regions to homogenise their attributes is measured.

Table 1

Indicators of regional integration

\begin{tabular}{lll}
\hline \multicolumn{1}{c}{ Indicator } & \multicolumn{1}{c}{ Definition } & Type of integration \\
\hline Population & $\begin{array}{l}\text { Number of people who can potentially be reached from any } \\
\text { border market in less than four hours }\end{array}$ & Interaction \\
\hline Water resources & Existence of shared surface water and aquifers & Interaction \\
\hline Agricultural and pastoral resources & $\begin{array}{l}\text { Existence of shared agricultural production basins and } \\
\text { transhumance patterns }\end{array}$ & Interaction \\
\hline Languages & Existence of major discontinuities between languages & Convergence \\
\hline Legal status of international borders & Existence of clearly demarcated and delineated borders & Convergence \\
\hline Political stability & $\begin{array}{l}\text { Existence of border disputes, conflicts and transnational } \\
\text { violent extremist groups }\end{array}$ & Interaction \\
\hline Poverty & Difference of poverty rates between contiguous regions & Convergence \\
\hline
\end{tabular}

Source: OECD/SWAC 2017

The examination of regional integration indicators in combination leads to a summary of the co-operation potential of West African borders. A number of points are allocated to each border segment separating the 179 administrative regions in West Africa, according to the intensity of cross-border co-operation that has been observed-low, medium or high (Table 2). Co-operation potential is considered to be at its height, for example, when a given region has clearly delimited and demarcated borders (status of borders). If just one of these conditions is met, co-operation potential is ranked medium, and the complete absence of delineation or demarcation is taken as a sign of weak potential. In terms of poverty, co-operation potential is highest when inequalities between border regions are neither too wide nor too narrow, as such gaps reduce either the opportunity or the motivation to co-operate. Assigning standardised scores then spotlights the areas that, potentially, are the most conducive to co-operation. 
Table 2

Cross-border co-operation potential

\begin{tabular}{|c|c|c|c|}
\hline & & Potential & \\
\hline Indicator & $\begin{array}{c}\text { High } \\
3 \text { points }\end{array}$ & $\begin{array}{l}\text { Medium } \\
2 \text { points }\end{array}$ & $\begin{array}{l}\text { Low } \\
1 \text { point }\end{array}$ \\
\hline Population potential & $\begin{array}{l}\text { Number of people who can be } \\
\text { reached within } 0-120 \text { minutes }\end{array}$ & $\begin{array}{l}\text { Number of people who can be } \\
\text { reached within } 121-240 \text { minutes }\end{array}$ & $\begin{array}{l}\text { Number of people who } \\
\text { can be reached within } \\
240 \text { minutes }\end{array}$ \\
\hline Water resources & Shared surface and ground water & Shared surface or ground water & $\begin{array}{l}\text { No shared surface or } \\
\text { ground water }\end{array}$ \\
\hline $\begin{array}{l}\text { Agricultural and } \\
\text { pastoral resources }\end{array}$ & $\begin{array}{l}\text { Shared agricultural basins and } \\
\text { pastoral itineraries }\end{array}$ & $\begin{array}{l}\text { Shared agricultural basins or } \\
\text { pastoral itineraries }\end{array}$ & $\begin{array}{l}\text { No shared agricultural } \\
\text { basins or pastoral } \\
\text { itineraries }\end{array}$ \\
\hline Languages & $\begin{array}{l}\text { No discontinuities between } \\
\text { vernacular, vehicular and } \\
\text { colonial languages }\end{array}$ & $\begin{array}{l}\text { Some discontinuities between } \\
\text { vernacular, vehicular and } \\
\text { colonial languages }\end{array}$ & $\begin{array}{l}\text { Strong discontinuities } \\
\text { between vernacular, } \\
\text { vehicular and colonial } \\
\text { languages }\end{array}$ \\
\hline Status of borders & $\begin{array}{l}\text { Borders clearly delineated and } \\
\text { demarcated }\end{array}$ & $\begin{array}{l}\text { Borders clearly delineated or } \\
\text { demarcated }\end{array}$ & $\begin{array}{l}\text { Borders neither delineated } \\
\text { nor demarcated }\end{array}$ \\
\hline Political stability & $\begin{array}{l}\text { No border conflict or } \\
\text { transnational extremist groups }\end{array}$ & $\begin{array}{l}\text { Occasional political instability in } \\
\text { border regions }\end{array}$ & $\begin{array}{l}\text { Border conflicts or major } \\
\text { transnational extremist } \\
\text { groups }\end{array}$ \\
\hline Poverty & Limited differential (10.4-24.0) & & $\begin{array}{l}\text { Very small or very wide } \\
\text { differentials } \\
(0-10.3 \text { and } 24.1-100)\end{array}$ \\
\hline
\end{tabular}

Source: OECD/SWAC 2017

Mapping co-operation potential reveals wide disparities between regions divided by a land border in West and North Africa (Map 1).

Map 1

Cross-border co-operation potential

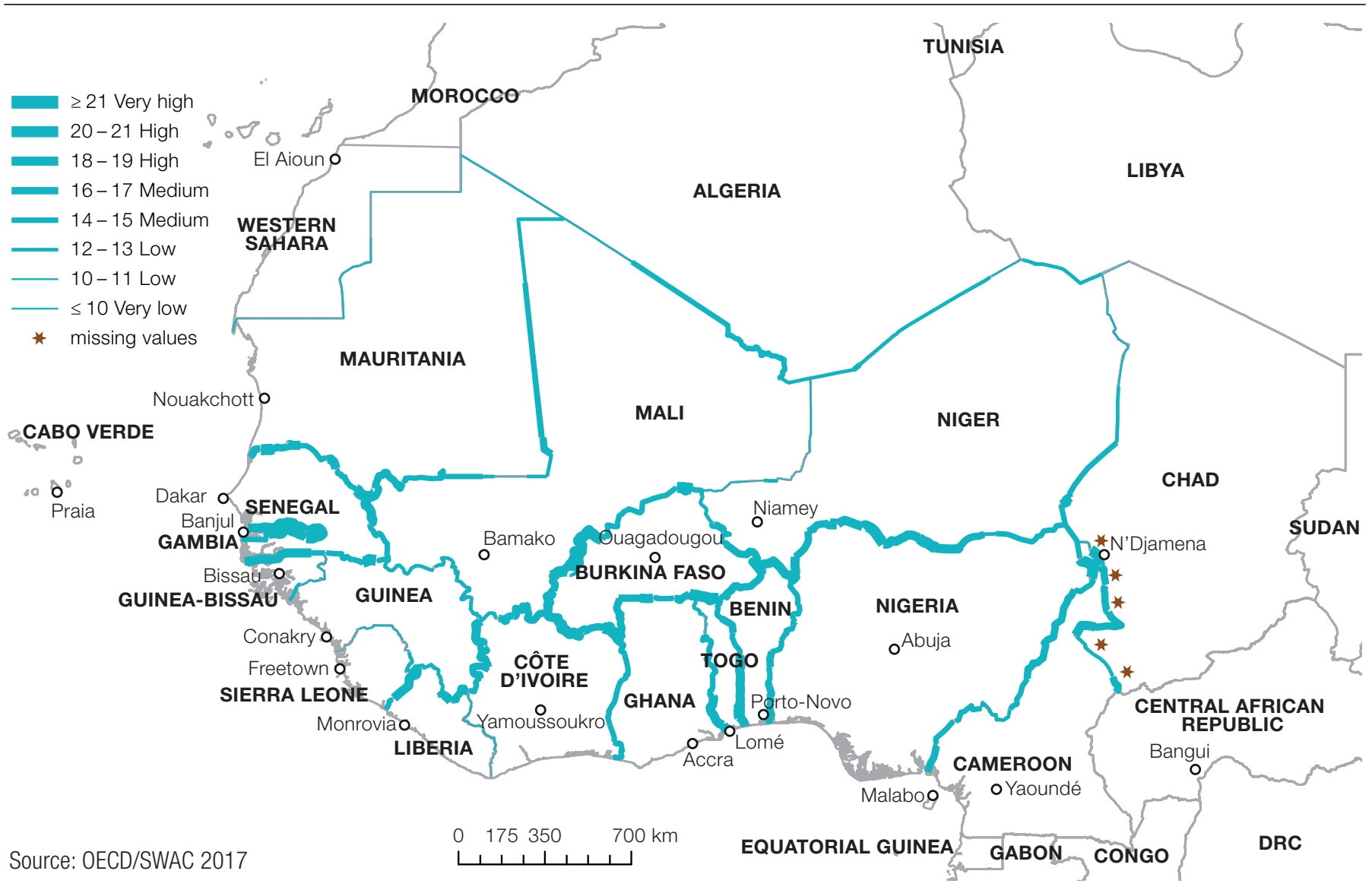


- Generally speaking, the Sahel-Saharan areas have the lowest co-operation potential, owing mainly to low levels of settlement (Map 2) and agricultural resources, and to political instability, especially in Mali since the early 2000s, following the arrival of religious extremists and separatists' claims for independence.

- $\quad$ On the whole, the Sahel is characterised by high co-operation potential, as may be seen in southern Senegambia, on the borders of Burkina Faso and between Niger and Nigeria. These regions, with their numerous border markets, are densely populated and share water, agricultural and pastoral resources which encourage the creation of cross-border production and trade networks. In addition, there is little language fragmentation, they are relatively unaffected by political instability and the poverty gaps are moderate. From an institutional viewpoint, the presence of borders that are recognised internationally and demarcated on the ground facilitates cross-border co-operation.

- The border regions in the Gulf of Guinea are more heterogeneous. Whereas many border segments in Sierra Leone, Guinea and Liberia seem to discourage cross-border co-operation owing to the low density of border markets, the uncertain status of their borders and the relative lack of shared resources, some regions have very high values, such as the area between Ghana, Togo and Benin. From this point of view, the AccraLagos conurbation seems to be particularly conducive to cross-border co-operation.

Map 2

Population potential of border markets

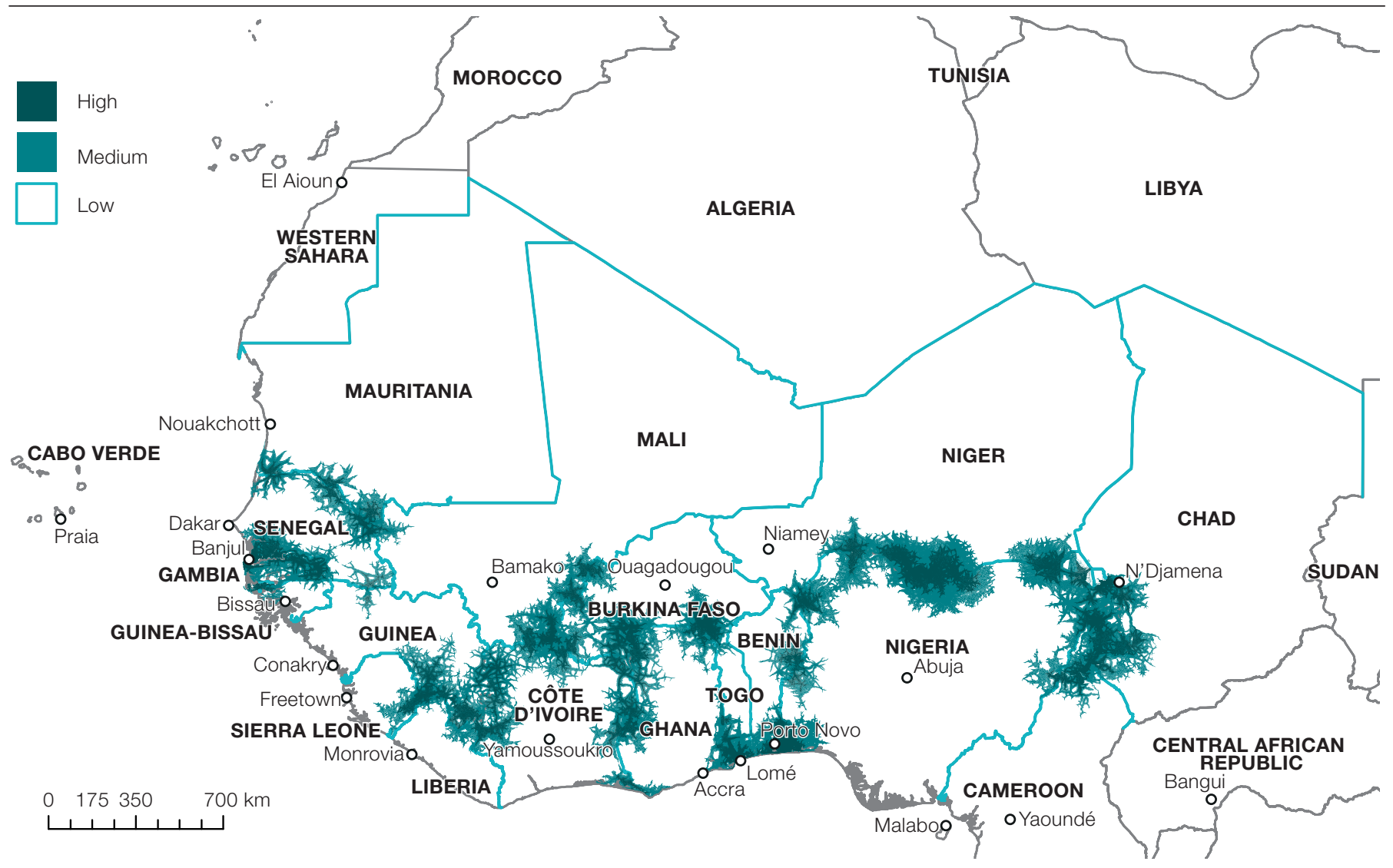

Source: OECD/SWAC 2017 
Calculating co-operation potential is a vital first step in studying the geography of crossborder co-operation in West Africa, but it is not sufficient. The intensity of co-operation cannot simply be measured on the basis of these regions' potential, which may or may not be leveraged by socio-economic and political actors. In order to show how the current borders could nourish the regional integration process, an analysis is required of the region's governance networks.

\section{Current situation: Where is cross-border co-operation being developed?}

By analysing the structure of governance networks it is possible to identify the actors involved in cross-border co-operation, to map their formal and informal connections and to assess the impact of national borders on the exchange of information and power. This analysis is based on a unique survey of 137 actors involved in cross-border co-operation across the entire West African region and in three micro-regions: the Senegal River valley, Liptako-Gourma, and the Lake Chad basin (Map 3). Each of these regions has a sectoral organisation responsible for promoting cross-border interaction: the Senegal River Basin Development Organisation (OMVS), Integrated Development Authority of the LiptakoGourma Region (ALG), and the Lake Chad Basin Commission (LCBC).

Map 3

West Africa and the micro-regions analysed

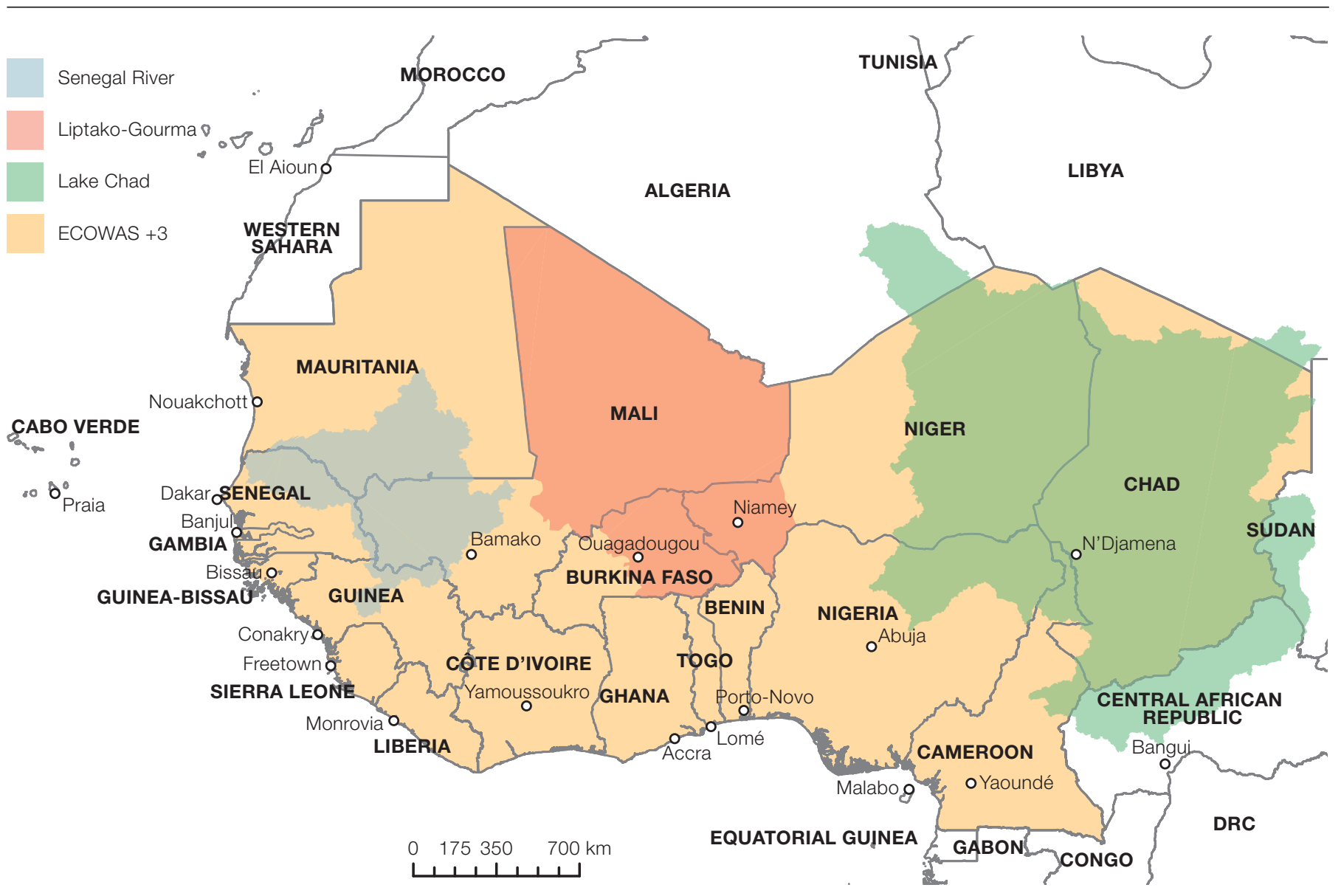

Source: OECD/SWAC 2017 
The governance networks are recreated using social network analysis, which focuses on the links maintained between actors in a specific area of activity. Several rounds of faceto-face interviews with actors involved in cross-border co-operation are used to draw up a map of the networks and measure the centrality of each actor.

The interviewees are first asked to name the people with whom they personally exchanged information within the context of cross-border co-operation between 2013 and 2015. This allows the information network connecting the cross-border co-operation actors to each other to be reproduced. The interviewees are then invited to name the actors they consider to be the most important in the field of cross-border co-operation in West Africa or in each of the three micro-regions under analysis. This information then allows the power network linking the actors of cross-border co-operation over the last two years to be established.

At the level of West Africa, the analysis of information exchange and power relationships shows that governance networks are dominated by intergovernmental organisations like the AU, ECOWAS, UEMOA and the Permanent Inter-State Committee for Drought Control in the Sahel (CILSS), which account for almost $70 \%$ of actors (Figure 1). It is within these organisations that contact is most frequent, with over one third of cross-border co-operation connections.

Figure 1

Network composition by type of actor

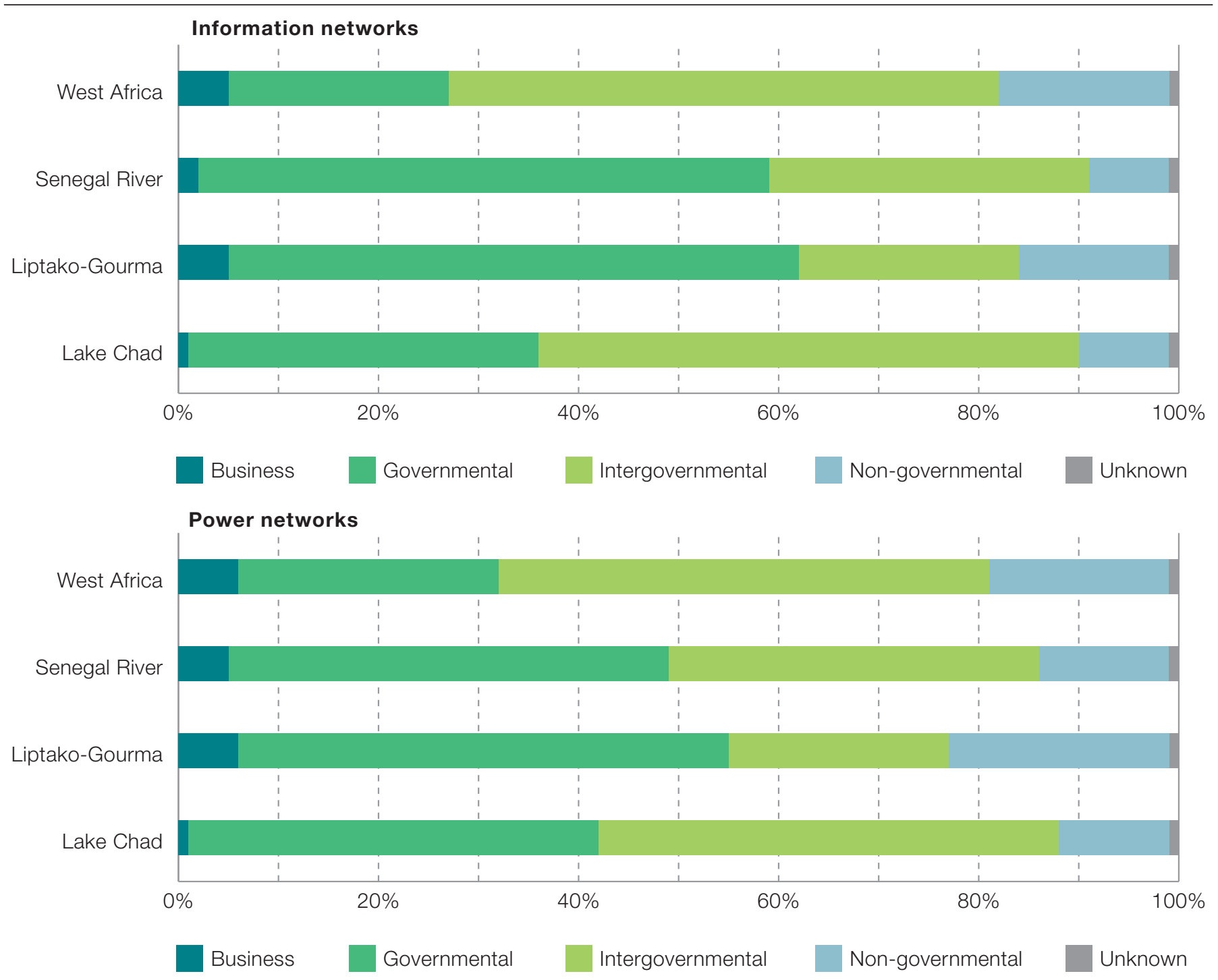


The micro-regions' networks typically contain a high proportion of governmental organisations, because of the importance of the national directorates involved in issues surrounding water, the environment and agriculture within the OMVS, ALG and the LCBC, for which most of the central actors work.

- In the Senegal River valley, a quarter of connections between actors in the information network are internal to inter-governmental organisations whereas the power network is mainly formed by relations within governmental organisations (one third of connections).

- In the Liptako-Gourma region, a third of information and power relations are internal to the various governmental organisations operating in cross-border co-operation between Niger, Mali and Burkina Faso.

- Around Lake Chad, intergovernmental organisations dominate the information and power network, accounting for over half the number of actors. Relations within these organisations represent over a quarter of total relations.

The research also reveals that the structure of the West African information network resembles the structure set up by the local actors in the three micro-regions under examination: these governance networks present low levels of density (few links between actors) and are relatively decentralised, an organisation that seems to promote the circulation of information between partners with widely varying statuses and skills. Decentralised structures also provide co-operation actors-who are often operating in a non-binding institutional environment—with greater flexibility than structures that are central to a single country or organisation.

These networks also contain a great many brokers, who are responsible for connecting sub-groups which have few direct relations, such as representatives of livestock farmers and representatives of governmental and intergovernmental agencies in the LiptakoGourma region, for example. The role of these brokers is especially visible in Figure 2, which shows each individual actor in proportion to the betweenness centrality at the level of the West African region as a whole. The betweenness centrality is a measure of global centrality indicating whether social actors establish relations between groups that are otherwise unconnected. The most significant brokers operate within ECOWAS: four representatives of that body rank among the network's ten most central actors.

What role do borders play in these networks? Based on the principle of homophily, which assumes that cross-border co-operation actors tend to favour social relations with other actors sharing the same attributes, such as nationality or belonging to the same organisation, the analysis reveals that governance networks are affected by borders to different degrees.

At the regional level, these networks seem to be closely aligned with national borders, especially between actors located in Africa and Europe. Regional networks present a high level of homophily: over $67 \%$ of relations connect actors on the same continent (Table 3). These results are corroborated by the E/I index, which is a measure of the difference between the internal and external relations of each country or continent, divided by the total number of relations between actors in a network. This index is very clearly negative, and relatively high, confirming the homophily of West African networks. 
Figure 2

Brokers in the West African information network

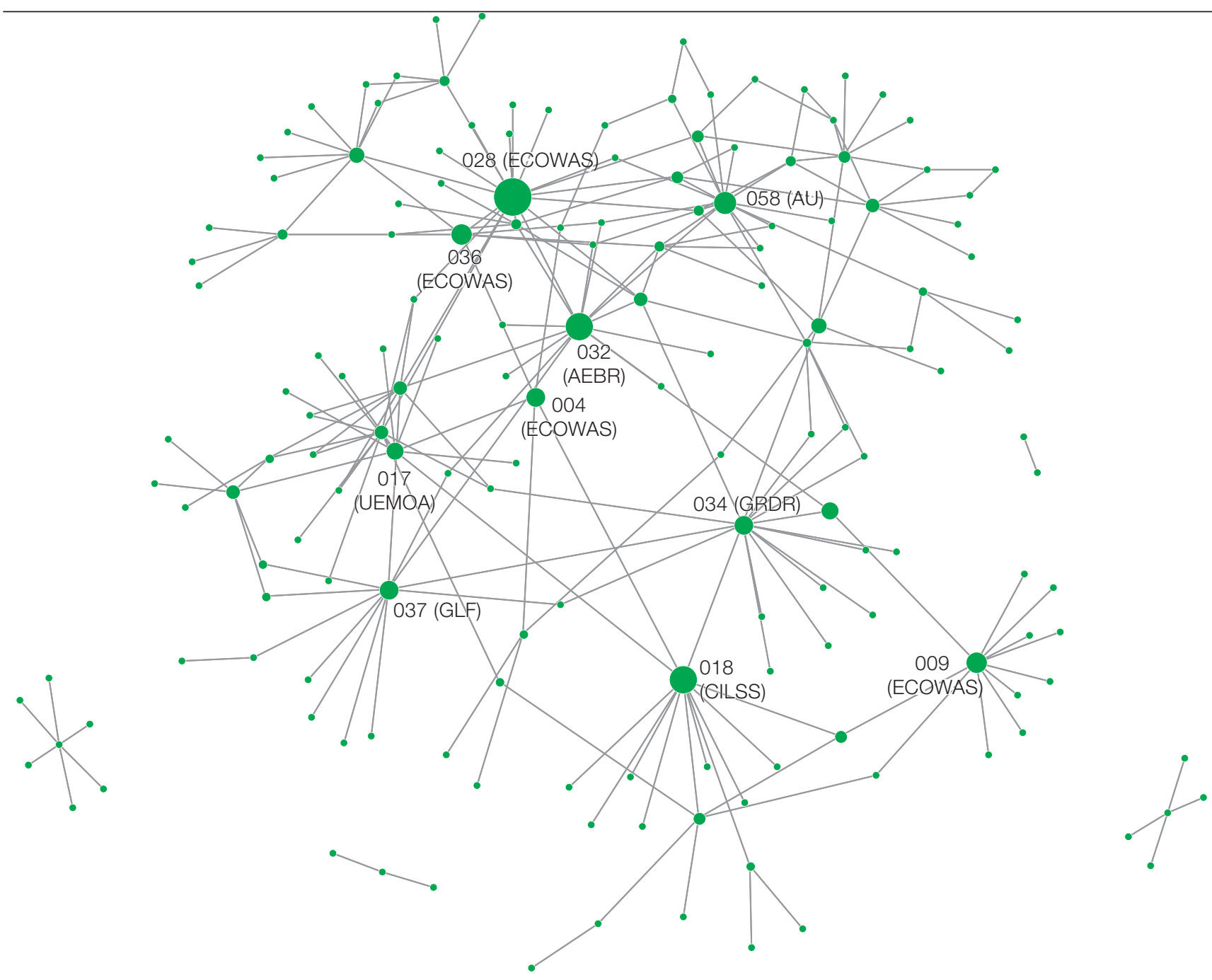

Source: OECD/SWAC 2017. Note: the figure displays the codes and relations of the ten most central actors only. Actors involved in cross-border co-operation are represented by circles that are proportional in size to their role as brokers within the network. Acronyms: Economic Community of West African States (ECOWAS), African Union (AU), Permanent Inter-State Committee for Drought Control in the Sahel (CILSS), West African Economic and Monetary Union (UEMOA), Group for Rural Development Research and Projects (GRDR), Association of European Border Regions (AEBR), Global Local Forum (GLF).

The effect of borders on networks is attenuated at the level of the three micro-regions under examination, where the institutional initiatives designed to foster the emergence of cross-border regions are pushing actors to increase communication with partners in other countries. In the Liptako-Gourma region, for example, low homophily scores, at between 29 and 35\%, suggest that the actors have a diverse network of partners in several countries, and do not systematically default to their own country, which is a sign of maturity in cross-border co-operation. In the information network, Malian actors (in green) are, for example, well connected to their Burkinabé counterparts (in blue) (Figure 3). Nigerien actors (in brown) also feature prominently, by virtue of their many connections and their role as intermediaries between other actors in the network (in beige). 
$\underline{\text { Table } 3}$

Homophily by region

\begin{tabular}{lcccc}
\hline & \multicolumn{2}{c}{ Information network } & Power network \\
\hline & Homophily (\%) & Index E/I & Homophily (\%) & Index E/I \\
\hline West Africa & 67.5 & -0.350 & 67.6 & -0.352 \\
\hline Senegal River & 28.8 & $0.424^{* *}$ & 36.4 & $0.273^{\star *}$ \\
\hline Liptako-Gourma & 34.8 & $0.303^{* *}$ & 29.1 & $0.419^{*}$ \\
\hline Lake Chad & 21.0 & $0.581^{*}$ & 20.0 & 0.599 \\
\hline
\end{tabular}

Source: OECD/SWAC 2017. Notes: The E/I index varies between 1 and -1. A strongly negative value denotes a highly homophilous network (actors exchange mostly within their own country), and a strongly positive value denotes a highly heterophilous network (actors exchange with no regard for borders). Two asterisks $\left(^{* *}\right)$ indicate that the $E / /$ index is significant at $5 \%,(p<0.05)$, and one asterisk (*) indicates that it is significant at $10 \%(p<0.1)$.

Figure 3

Information network in the Liptako-Gourma region by country

Burkina Faso

Mali

Niger

Other
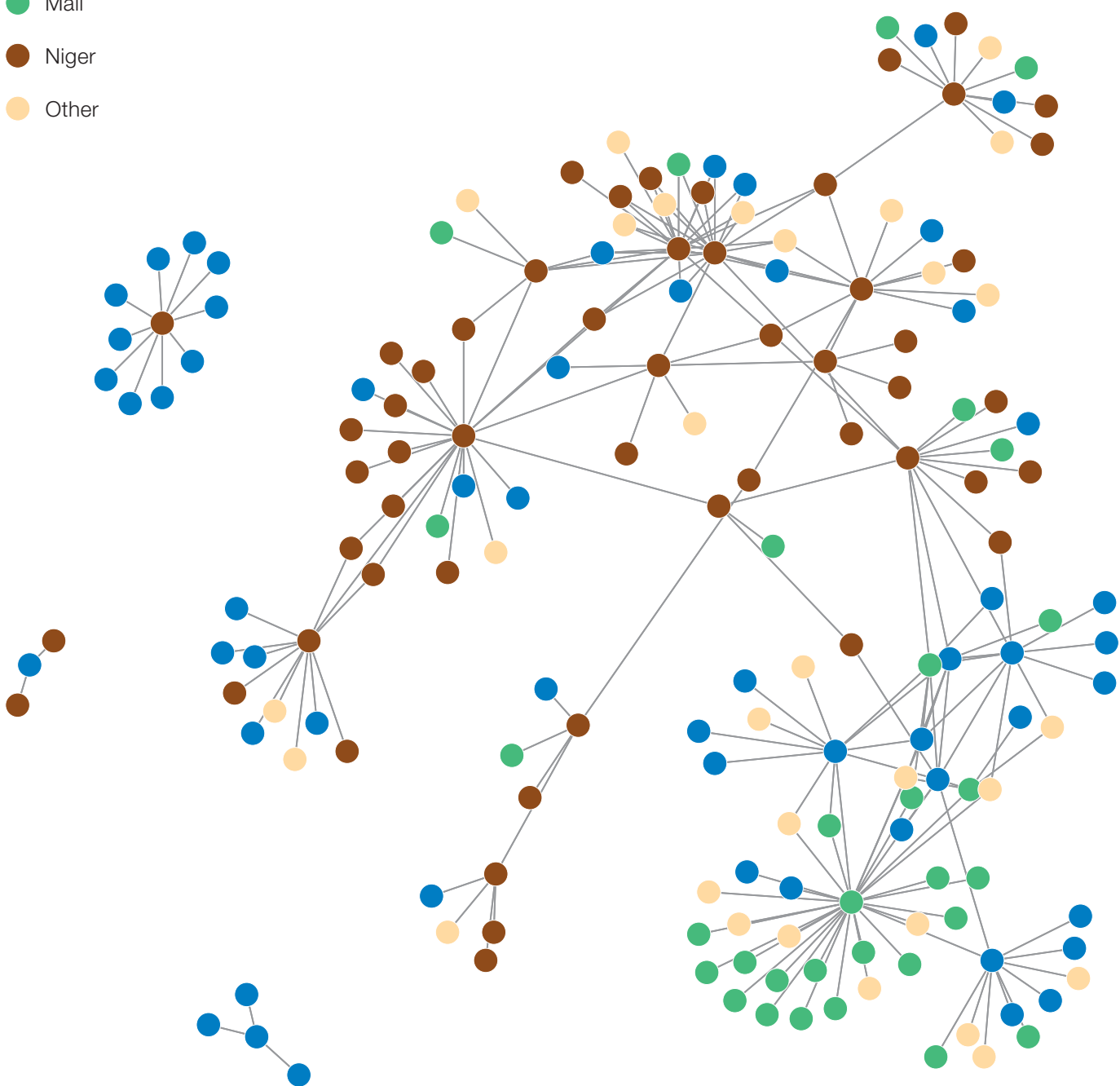

Source: OECD/SWAC 2017 
The Lake Chad region also exhibits a low tendency towards homophily, especially for actors located in Niger and Nigeria, which are densely connected to their counterparts in neighbouring countries regardless of the type of network (information or power). The governance network in the region is typified by actors who exchange beyond national borders, although mainly within their structure, namely the LCBC. It differs from the Senegal River valley network and the Liptako-Gourma region, in which cross-border co-operation actors are more willing to cross institutional barriers.

\section{Vision: Where should cross-border co-operation be developed?}

One of the thorniest questions facing the actors involved in cross-border public policies is knowing exactly where to develop co-operation. Is it preferable to set up border regions that are delineated by the administrative maps of the countries concerned? Would it be better to use physical markers that are harder to contest, such as catchment basins? Or is it better to constitute border regions based upon the shifting contours of the populations that interact and cross borders on a daily basis? Far from being anecdotal, the delimitation of the space selected for targeted cross-border co-operation will often determine the actors represented within governance structures, where investments are concentrated and the power relationships between border regions and other levels of authority.

The focal space for co-operation can be reconstructed from the spatial perceptions of the actors involved in cross-border co-operation. Regional construction is based on a vision of the cross-border zones that is shared by co-operation partners. The goal is to chart these spatial representations by identifying priority regions for cross-border co-operation in West Africa, in the region around the Senegal River, in Liptako-Gourma and in the Lake Chad basin. This work is based on a unique analysis of 137 simplified maps known as mental maps, on which each interviewee draws the boundaries of what they perceive to be the focus of co-operation and indicates where the relevant strategic decisions are taken (Map 4).

Superimposing all the mental maps first establishes whether a consensus exists on the geographical extent of cross-border co-operation. The maps show which regions are considered as priorities for cross-border co-operation by a majority of actors, and those that are considered to be of lesser significance. The average area of the mental maps and their density by region are used to evaluate this geographical extent (Map 4). The mental maps are then used to assess to what extent each mental map is more or less dispersed in space with respect to the mean centre of all the maps of the region. The mean centre is more important in the micro-regions than across West Africa as a whole, given the vast extent of this region, which encourages the dispersal of the mental maps.

The analysis shows that the actors rarely agree on both the territorial extent and the mean centre of cross-border co-operation (Table 4). At the regional level, it is difficult to assume that consensus exists over the territorial extent of co-operation, given the wide variance in size between the respondents' mental maps. At most, the respondents located in West Africa have a more tempered vision of their region than those in Europe or the rest of Africa.

Several regions, however, are recognised as centres of gravity for cross-border co-operation, particularly the Lagos-Cotonou conurbation, Dendi, the Hausaland, the border between Togo and Burkina Faso, and the Sikasso-Korhogo-Bobo Dioulasso triangle (Map 5). The western and northern sections of Nigeria, Lomé, Lake Chad, the tripoint between Mali, Mauritania and Senegal, and the Burkina Faso-Ghana border are considered to be more in the second tier of priority regions, whereas the intermediary strip between the Gulf of Guinea and the Sahel is considered to be a low priority for cross-border co-operation. 
$\underline{\text { Map } 4}$

Mental maps by locality

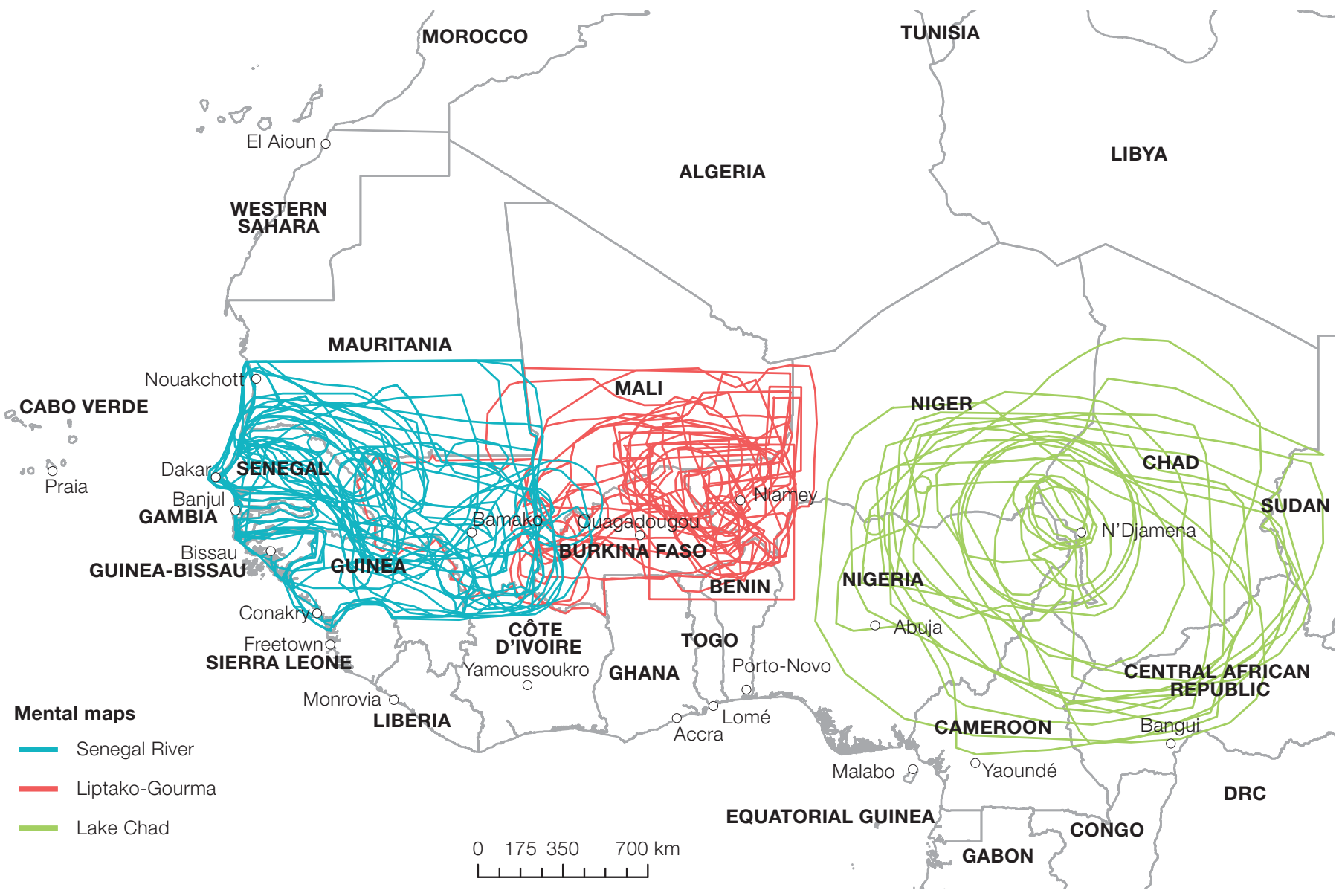

Source: OECD/SWAC 2017

Table 4

Consensus over the extent and mean centre of cross-border co-operation

\begin{tabular}{lcc} 
& Geographical extent & Mean centre(s) \\
\hline West Africa & No & Yes \\
\hline Senegal River valley & Yes & No \\
\hline Liptako-Gourma & Yes & Yes \\
\hline Lake Chad region & No & Yes \\
\hline
\end{tabular}

Source: OECD/SWAC 2017 
$\underline{\operatorname{Map} 5}$

Priority areas for cross-border co-operation in West Africa

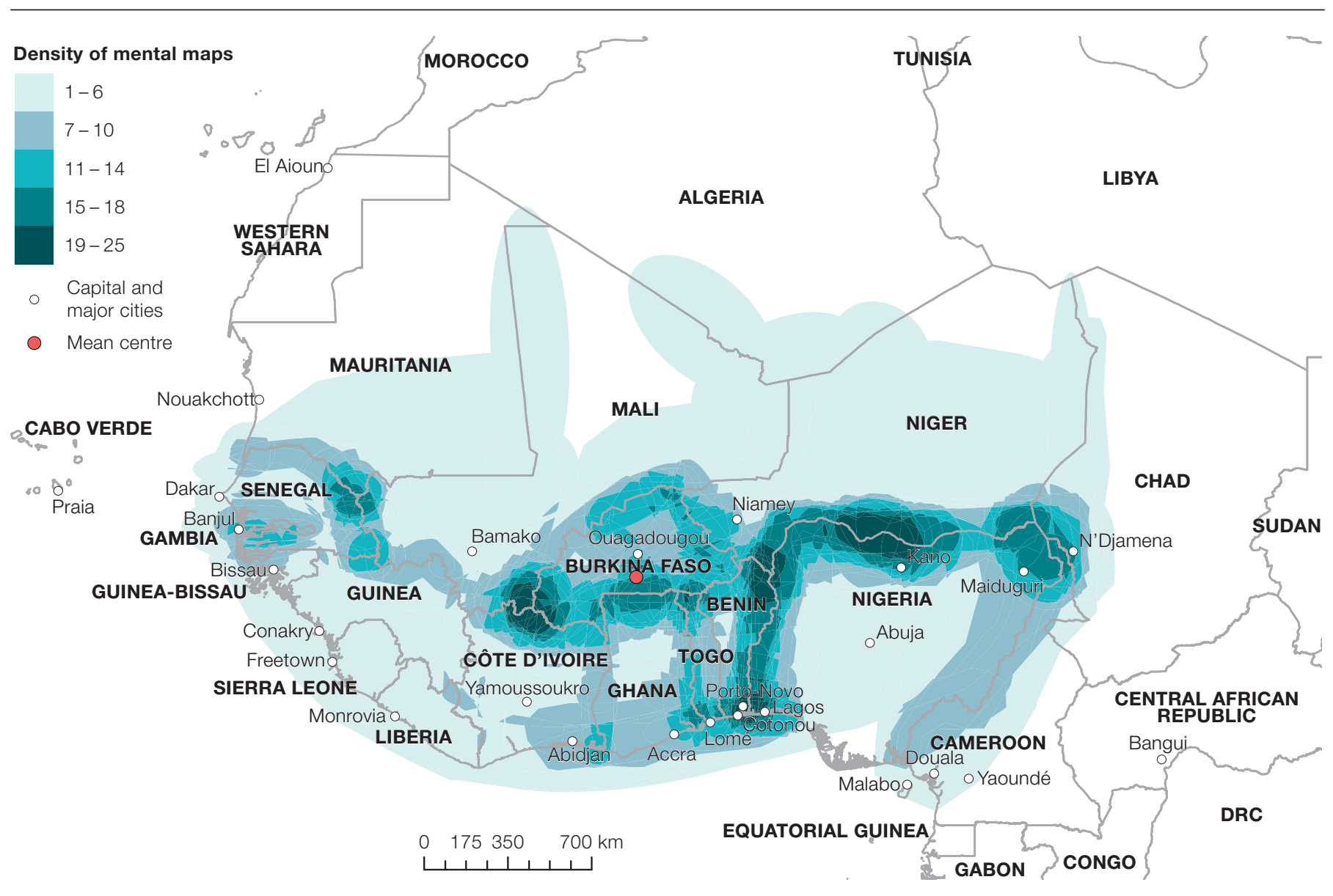

Source: OECD/SWAC 2017

- In the Senegal River region, there is consensus over the territorial extent of crossborder co-operation, which follows the river valley and the border between Senegal and Mali, but not over the mean centre, which is highly variable. The area recognised as a priority, which stretches along for approximately $100000 \mathrm{~km}^{2}$, is scarcely a third of the size of the Senegal River basin and corresponds to the southern section of the area under the authority of the OMVS.

- In Liptako-Gourma, consensus exists over both the territorial extent and the mean centre of cross-border co-operation. The priority area for cross-border co-operation traces a crescent through the tripoint between Burkina Faso, Niger and Mali and from the Niger River valley to Niamey. This zone of about $50000 \mathrm{~km}^{2}$ roughly corresponds to the heart of the restricted area of the ALG, which itself is almost seven and a half times the size.

- In the Lake Chad basin, the actors agree that the centre of cross-border co-operation is confined to the area delimited by N'Djamena, Maiduguri and Diffa but disagree on the geographic reach, which for some goes as far as the Central African Republic, southern Chad and central Niger. The most central recognised zone of $176000 \mathrm{~km}^{2}$, represents only one-sixth of the Lake Chad basin, over which the LCBC exercises its authority. 
In all regions, the priority area for cross-border co-operation is far more limited than that over which organisations such as the OMVS, ALG and LCBC exercise their authority (Map 6). The large size of West African institutions is the legacy of a time when there was a drive to build regions based on existing administrative bodies. However, this prevents smaller-scale cross-border investments, for example in urban centres which are considered to be the most central, such as Kaédi, Sélibaby and Kayes; Dori, Gao and Tillabéri; or N’Djamena, Maiduguri and Diffa.

The reality to date is that small and medium-sized West African cities are not centres of strategic decision making. The survey of 137 actors in the region confirmed that political decisions concerning co-operation are still taken in the region's capital cities. These strategic locations are primarily Abuja in Nigeria, where ECOWAS is headquartered, Ouagadougou in Burkina Faso, home to UEMOA and CILSS, and to a lesser extent Dakar in Senegal. These three cities represent nearly $40 \%$ of the places mentioned at least once by respondents as strategic for co-operation at the regional level.

At the local level, the capitals of the member states of sectoral organisations also feature among the most strategic places for co-operation, given that they are home to the sectoral cross-border co-operation organisations (Map 7).

- $\quad$ This is the case for the Senegal River valley, where Dakar, Bamako, Nouakchott and Conakry emerge strongly as the major centres of strategic decision making due to the rotating presidency of the OMVS. These key locations decisively outrank the more distant capitals of Niger and Burkina Faso, as well as regional centres such as Kayes, Sikasso and Ségou in Mali.

- In Liptako-Gourma, Ouagadougou is widely considered to be the most strategic location for co-operation because it is the headquarters of both UEMOA and the ALG. The other capitals of ALG member countries - Niamey and Bamako - are also viewed as particularly central. One of the names most frequently mentioned is Dori, a small town in Burkina Faso, whose strategic importance far outweighs its small size, due to the decentralised co-operation initiatives taken there in recent years. Liptako-Gourma appears to be an area whose potential is exploited by crossborder governance networks, in particular along the border between Burkina Faso and Niger . This region is also characterised by a large number of local initiatives and a dense network of actors working for numerous small and medium-sized decision-making centres. This polycentrism, combined with the very real dynamism of the municipalities, can be considered as an advantage in the implementation of bottom up integration programmes.

- In the Lake Chad region, strategic decisions on cross-border co-operation are chiefly taken in N'Djamena, followed by the capitals of neighbouring countries. The region may be home to the oldest river basin organisation in Africa but it does not have many connections to regional governance networks. At the local level, the focus of the governance network on LCBC actors does little to enhance border areas, especially between Chad and Cameroon. 
Map 6

Priority areas for cross-border co-operation in the micro-regions
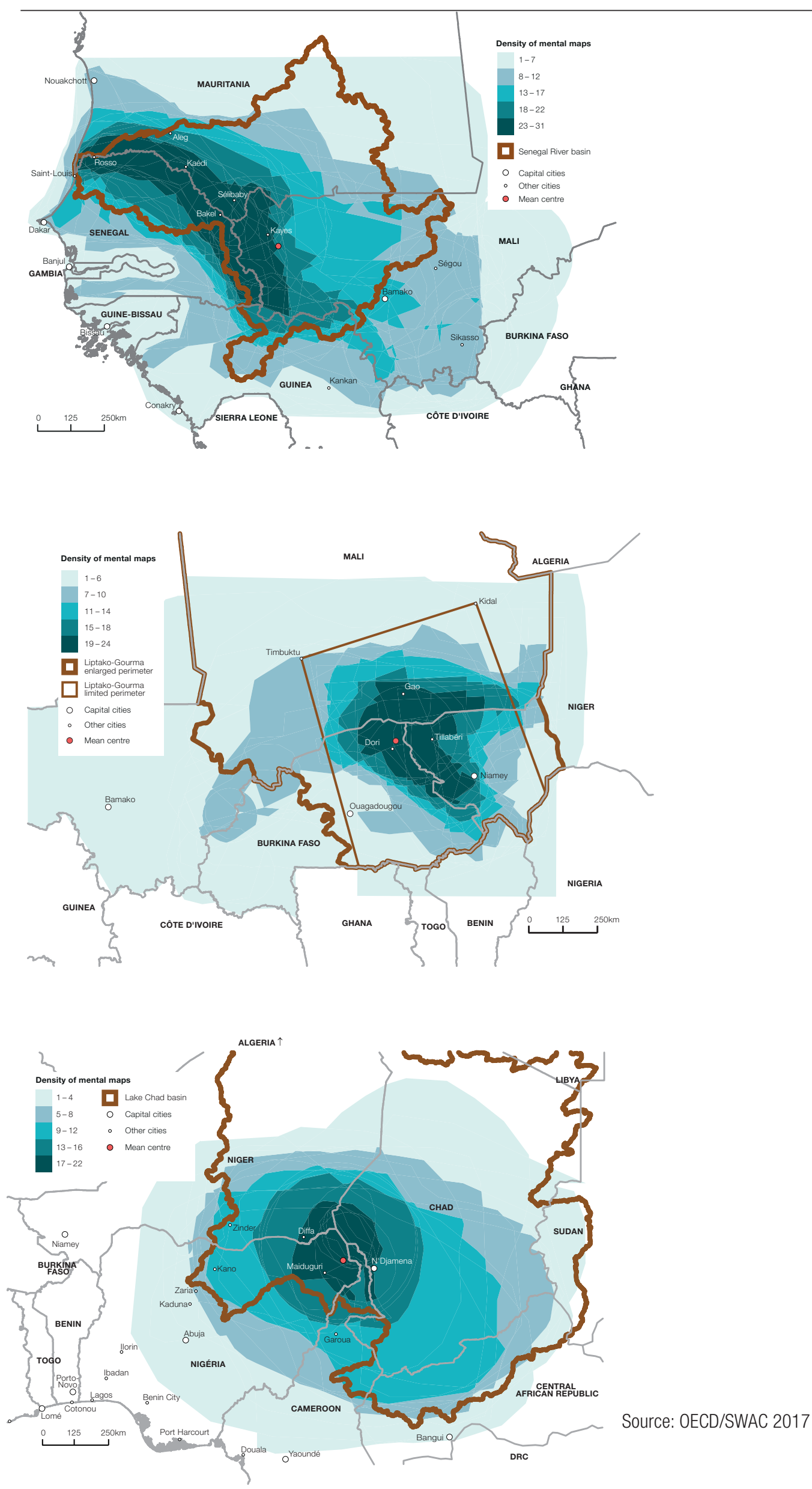
Map 7

Strategic areas for cross-border co-operation at the local level

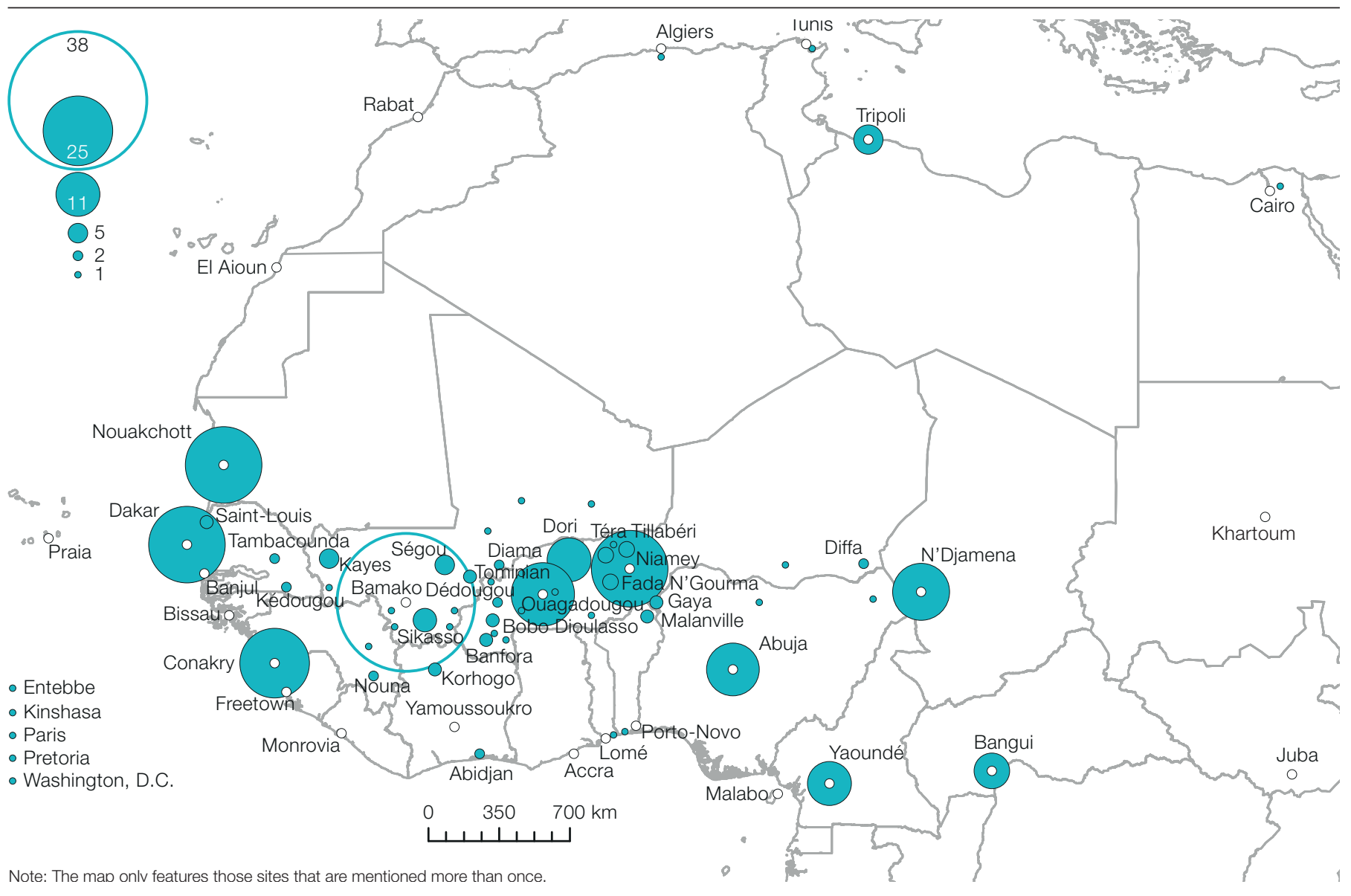

Source: OECD/SWAC 2017

\section{COMBINING THE THREE DIMENSIONS OF CROSS-BORDER CO-OPERATION}

C

ross-border co-operation policies can be considered to be fully integrated if they are based on a demonstrable potential for integration, a functional governance network, and a shared policy makers' vision. This ideal situation characterises a small number of regions, including western Mali, the SKBo triangle, Liptako-Gourma, Dendi, the LagosAccra conurbation and northern Ghana. In the rest of West Africa, significant political, institutional and financial constraints on the design and implementation of cross-border policies explain the gap between the regions' potential, governance and political vision. Three main situations can be observed.

\section{Untapped co-operation potential}

The first situation concerns regions which have potentially favourable conditions for co-operation but where local actors are not particularly well connected to governance networks. The borders of Gambia, Sierra Leone and Liberia are representative of this situation, which reflects untapped potential. Despite the fact that each one of these regions has an intergovernmental body potentially capable of managing cross-border co-operation at the local level - the Gambia River Basin Organisation (OMVG) and the Mano River Union (MRU) - their involvement in West African networks remains marginal. The capital cities and major towns in these four countries do not host any actors with a particularly central role in co-operation, or any regional institutions to rival the ones in Ouagadougou and Abuja. 


\section{Poorly developed governance networks}

The second situation concerns regions which are recognised as being priorities for cross-border co-operation, but which have poorly developed local and regional governance networks. A significant gap between political vision and effective cross-border governance can be caused by a lack of initiative by local actors, a preference for personal interaction outside of formal governance structures, shortcomings in the exchange of information between border countries, or an inclination to give priority to exchanges between actors from the same country rather than to cross-border relationships. In all of these situations, using social network analysis to study the very structure of the governance networks can reveal any institutional blockages, and highlight any untapped potential for creating a network across national borders.

\section{Political priorities}

Political trade-offs are the most likely explanation for a failure to prioritise regions exhibiting potentially favourable conditions for cross-border co-operation. Some regions, such as the northern border between Togo and Benin, or southern Senegambia, could be in favour of co-operation but their development has not received political recognition due to balances in the political relationships between national elites and local and regional authorities. Centralised states tend to focus their investments on a small number of urban regions, in particular around capital cities, so long as decentralisation is not accompanied by an actual transfer of resources and power to local and regional authorities.

For federal states or those which have pursued genuine decentralisation, the issue is not so much about determining whether investments should be distributed on a fairer geographic basis but rather about prioritising those which can actually be funded out of the public financing available. This is the case in eastern Nigeria, where high co-operation potential has not resulted in political priority status due to the fact that most of the co-operation resources allocated by the federal state and its regions are focused around Lake Chad.

\section{THE FUTURE OF CROSS-BORDER CO-OPERATION}

$\mathbf{T}$ he public policies implemented by the regional organisations, the West African states and their international partners can help encourage cross-border co-operation by adopting place-based policies tailored to the specificities of each region and by developing a more specifically West African integration model.

\section{Tailoring policies to regions' specificities}

To date, most policies developed in West Africa promote certain sectors, such as industry and livestock, or certain categories of the population, such as the most vulnerable, without necessarily taking into account the spatial dimensions of regional development. As a result, regional disparities are largely neglected, despite the critical role they play at the expense of inclusive growth (ADB/OECD/UNDP, 2015). Policies designed to encourage cross-border co-operation need to break this pattern and build on the great diversity of the West African regions. In order to be effective, these policies need to become place-based strategies which take account of the variety of needs, institutional systems and development levels in the West African regions, and provide public goods adapted to the specific socio-economic challenges of each region. Densely populated border regions like northern Nigeria and Niger's Hausaland, or the Lake Chad basin, for example, have different needs from those of sparsely populated areas such Hodh on the border of Mauritania and Mali. Coastal and more industrial belts such as the Accra-Lagos conurbation require policies that are of little use to agricultural regions in northern Ghana.

These place-based strategies assume that actors and local institutions can be mobilised to support regional development (OECD, 2009; Barca et al., 2012). In contrast to conventional regional policies which are based on top-down sectoral interventions and which rely on subsidies, territorial policies are designed to promote spatial integration by investing 
in infrastructure and public goods tailored to the context of each area. These policies are based on the idea that local actors and institutions shape the development potential of cross-border co-operation and can be mobilised to foster economic development. They adapt to the local circumstances within which regionalism occurs to help develop tailored cross-border co-operation initiatives across the length of West Africa's 32000 $\mathrm{km}$ of borders.

The strong heterogeneity of West African border areas suggests that investments are concentrated in the regions with the most potential, which have already created governance networks or which are considered to be a priority by policy makers. In the other regions where there is untapped co-operation potential or political consensus on the importance of border co-operation, but where governance networks are still poorly developed, the objective of place-based policies is to encourage the emergence of cross-border networks of actors. This can be achieved by encouraging the creation of appropriate institutions, reducing the excessive trans-border differentials that limit possibilities for collaboration, preventing local and international conflicts, and by fostering mutual understanding of actors in the neighbouring country.

The situation of regions with strong co-operation potential but which are not prioritised by policy makers is the most restrictive in terms of cross-border development, as the construction of micro-regions presupposes that local and regional authorities are sufficiently autonomous in terms of resources and power to make their interests heard by central government. Without institutionally strong regions, it is difficult to talk of regional construction. In order to exploit the co-operation potential of these regions, the positive repercussions of an increase in cross-border interaction need to be highlighted.

\section{An integration model between institutions and functional interactions}

The political vision of cross-border co-operation that is conveyed in West Africa borrows from the two main regional integration models developed world wide, without actually resulting in a model suited to African specificities.

On the one hand, the historical experience - and the institutional and financial support - of the European Union (EU) encourages West African states to adopt an integration model focused primarily on institutions. This model relies on the prior construction of formal cross-border co-operation structures which are tasked with promoting closer relations between border actors, and with encouraging socio-economic exchanges. The sectoral regional organisations created in these countries in the 1960s, such as the OMVS, the ALG and the LCBC, provide an illustration of this model which prioritises political construction. The increasing integration between border regions is perceived as an outcome of efforts undertaken by this institutional framework.

On the other hand, there has been an increase in recent years in the number of initiatives influenced more strongly by - and receiving more financial support from - an integration model which focuses on interactions between socio-economic actors and which is particularly prevalent in North America. This model is based on border territories complementing one another in functional areas through the creation of ad hoc co-operation structures responsible primarily for reducing the frictions that hinder regional trade. This is reflected in the creation of adjacent border posts, the reinstatement of transport corridors, and the removal of the informal controls and practices that had led to a fragmentation of the regional area which was particularly costly for cross-border economic operators in West Africa (USAID 2015). Under this model, the purpose of cross-border co-operation structures is to facilitate flows of goods and people. The result is smaller structures, which are sometimes privately owned, and which involve public authorities and relevant businesses in equal measure when dealing with a specific issue such as transport or the environment. These structures favour networking between the actors, regardless of their administrative level. 
The current co-existence of these two integration models in West Africa allows for the diversification of cross-border co-operation structures and opens access to the funding provided by both models. Against a backdrop of both a certain proliferation of intergovernmental organisations and a preponderance of informal interactions, it is by no means certain that either of these models is properly suited to the opportunities and constraints facing the state and non-governmental actors in West Africa.

The advantage of the European-inspired heavily institutionalised model is that it creates structures that are easily identifiable for international donors; however it also propagates bureaucratic structures. Insofar as the main aim of cross-border co-operation is to create sub-regional groupings, this model naturally ends up favouring territorial representatives such as states, regions and local authorities, while non-territorial and private actors are often absent. Conversely, while the merit of the flexible model which originated in North America is that it focuses its actions on a limited number of functional problems, it often conflicts with the interests of West African states, for whom cross-border co-operation is a political field like any other, and for whom the frictions hampering regional integration are a source of income. In the long term, the success of cross-border co-operation will be based on the implementation of a more specifically West African integration model, one which takes into more rigorous consideration the region's socio-economic and political specificities.

\section{USING A RELATIONAL APPROACH TO UNDERSTAND CROSS- BORDER CO-OPERATION}

\footnotetext{
C ross-border co-operation is an integration process which should be approached more systematically from a relational standpoint, i.e. by considering the interactions between its actors. A focus directed solely on the institutional attributes of regional organisations, states and local authorities conceals how cross-border co-operation really works, and the fact that its effectiveness is often due to the interpersonal relations between actors of very different natures. Together these actors form a governance network which transcends both the administrative limits of states and their own internal divisions. The large number of actors involved in exchange of information and the decision making process prevent any form of simplification. In the Senegal River valley, for example, no fewer than 165 individual actors, interconnected by over 300 relationships, are directly involved in cross-border co-operation.
}

Unlike analyses based on creating a sample of statistically independent individuals, social network analysis seeks primarily to piece together all the relations within a social network. Accordingly, it takes into account the structural position of each actor, regardless of their hierarchical level, national affiliation or institutional authority. In this manner, social network analysis helps reposition social actors at the core of development studies, by considering them as a vital node in a cohesive social structure and not just a statistically interchangeable individual. Rather than focusing on collating a large number of attributes, such as gender, educational attainment or income, social network analysis also considers relations as its main unit of analysis. This focus on studying the ties that bind social actors is particularly suited to cross-border co-operation, the main objective of which is to foster interactions between partners separated by national borders.

The network analysis carried out in West Africa suggests that the general structure of networks heavily influences the exchange of information and power between actors. In this respect, decentralised networks are particularly suited to the constraints of crossborder co-operation, which requires constant co-ordination between actors with highly diverse skills. Network analysis also shows that regional integration is facilitated by both the involvement of co-operation actors in dense groups of partners (embeddedness) and 
the construction of ties which extend beyond the local level (brokerage). Embeddedness strengthens trust between like-minded actors, reduces risks related to project implementation and helps border regions to develop a common vision, while brokerage gives them access to new resources in other regions or at the level of regional organisations.

Social network analysis is an analysis tool for researchers in the social and economic sciences, an empowerment tool for local communities and non-governmental organisations (NGOs), and an intervention tool for international organisations and governments. The ability to visualise the real network of relations within a social group can help local communities shed light on the structural causes behind their marginalisation. In sub-Saharan Africa and Asia, these participatory approaches to social network analysis have been used by several international organisations in the fields of agriculture, natural resources management, and health (Schiffer, 2012).

Network analysis is also useful for understanding the social impact of development projects on local communities (World Bank, 2012). Whether it be for adopting new agricultural technologies, constructing water infrastructures or creating a health network, network analysis can help identify relevant issues that hinder community development, visualise the complexity of actors engaged in the resolution of issues, and represent the relationships between the issues themselves (Boutilier, 2011; Schiffer et al., 2012).

This type of approach, which is still rarely applied to the field of development, is therefore a research tool that is particularly well suited to understanding fluid social organisations which cannot be easily subdivided into predetermined categories, such as policy makers involved in cross-border co-operation. A range of new applications could also be found in other relational fields by nature, such as trade, migration and conflicts (Berrou and Combarnous, 2011; Walther 2014, 2015), provided that there is a more systematic gathering of relational data on business relationships between traders, interpersonal exchanges between migrants, and alliances and confrontations between armed groups. 


\section{REFERENCES}

AEBR (2012), Opportunities for Cross-border cooperation in West Africa: a contribution to the regional integration process, Association of European Border Regions, Gronau.

AfDB/OECD/UNDP (2015), African Economic Outlook 2015, Regional Development and Spatial Inclusion, OECD Publishing, Paris, http://dx.doi.org/ 10.1787/aeo-2015-en.

Barca, F., P. McCann \& A. Rodríguez-Pose (2012), "The Case for Regional Development Intervention: Place based Versus Place-neutral Approaches”, Journal of Regional Science, Vol. 52/1, pp. 134-152.

Berrou J.P. \& F. Combarnous (2011), "Testing Lin's social capital theory in an informal African urban economy", The Journal of Development Studies, Vol. 47/8, pp. 1216-1240.

Boutilier, R. (2011), A Stakeholder Approach to Issues Management, Business Expert Press, New York.

Enda Diapol (dir. pub.) (2007), Les dynamiques transfrontalières en Afrique de l'Ouest, Texts collected and presented by Enda Diapol, Éditions Karthala, Paris.

OECD (2009), How Regions Grow: Trends and Analysis, OECD Publishing, Paris, http://dx.doi.org/10.1787/9789264039469-en.

OECD/SWAC (2017), Cross-border Co-operation and Policy Networks in West Africa, West African Studies, OECD Publishing, Paris, http://dx.doi.org/10.1787/9789264265875-en.

Schiffer, E., A.Y. Mustapha \& A.L. Mustaph (2012), "Planning, budgeting and disbursing funds for newborn survival in Katsina State, Nigeria - a Net-Map analysis", Net-Map Toolbox, Washington, DC.

Schiffer, E. (2012), "Using Net-Map to assess and improve agricultural innovation systems", in Agricultural Innovation Systems: An Investment Sourcebook, World Bank, Washington, DC, pp. 593-597.

SWAC/OECD (2007), Practical guide to cross-border co-operation, CD-ROM, Paris, www.oecd.org/swac/publications/guide.htm.

USAID (2015), Report on road harassments, February, United States Agency for International Development, Washington.

Walther, O. (2015), "Business, brokers and borders: The structure of West African trade networks", The Journal of Development Studies, Vol. 51/5, pp. 603-620.

Walther, O. (2014), "Trade networks in West Africa: A social network approach", The Journal of Modern African Studies, Vol. 52/2, pp. 179-203.

World Bank (2012), Agricultural Innovation Systems: An Investment Sourcebook, World Bank, Washington, DC. 



\section{ALSO IN THE WEST AFRICAN PAPERS SERIES:}

Allen, T. and P. Heinrigs (2016), "Emerging Opportunities in the West African Food Economy", West African Papers, No. 1, OECD Publishing, Paris. http://dx.doi.org/10.1787/5jlvfj4968jb-en

Lewis, K. and C. Buontempo (2016), "Climate Impacts in the Sahel and West Africa: The Role of Climate Science in Policy Making", West African Papers, No. 2, OECD Publishing, Paris. http://dx.doi.org/10.1787/5jlsmktwjcd0-en

Gnisci, D. (2016), “Women's Roles in the West African Food System: Implications and Prospects for Food Security and Resilience", West African Papers, No. 3, OECD Publishing, Paris. http://dx.doi.org/10.1787/5jlpl4mh1hxn-en

Staatz, J. and F. Hollinger (2016), "West African Food Systems and Changing Consumer Demands", West African Papers, No. 4, OECD Publishing, Paris. http://dx.doi.org/10.1787/b165522b-en

Prieto Curiel, R., P. Heinrigs and I. Heo (2017), "Cities and Spatial Interactions in West Africa: A Clustering Analysis of the Local Interactions of Urban Agglomerations", West African Papers, No. 5, OECD Publishing, Paris. http://dx.doi.org/10.1787/57b30601-en

For more information on the series, please contact: lia.beyeler@oecd.org 